\title{
Psychological Aspects of Using Video for Forming Teenagers' Translational Competence
}

\section{Психологічні аспекти використання відео для формування перекладацької компетентності підлітків}

\author{
Ernest Ivashkevych \\ Ph.D. in Psychology, Assistant Professor of the Department of \\ Practice of English, the Translator, Rivne State University of the \\ Humanities, Rivne (Ukraine) \\ ORCID ID: https://orcid.org/0000-0001-7219-1086 \\ Researcher ID: http://www.researcherid.com/rid/F-3865-2019 \\ E-mail: ivashkevych.ee@gmail.com

\section{Ернест Івашкевич} \\ Кандидат психологічних наук, старший викладач кафедри \\ практики англійської мови, перекладач, Рівненський державний \\ гуманітарний університет, м. Рівне (Україна)
}

\section{ABSTRACT}

The aim of the article is to show the types of video material which help to develop the translational competence of teens; to determine the structural components of willingness of pupils to provide translational activity.

Methods of the research. As for general scientific methods, such of them as the method of induction, deduction, analysis and synthesis, comparative and descriptive methods and explanatory ones.

The results of the research. In this article we consider the development of the translational competence of schoolchildren from the standpoint of the cul-

Address for correspondence, e-mail: kpnu_lab_ps@ukr.net Copyright: (C) Ivashkevych Ernest

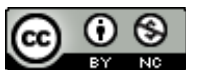

The article is licensed under CC BY-NC 4.0 International

(https://creativecommons.org/licenses/by-nc/4.0/)

(C) Ivashkevych Ernest

DOI (article): https://doi.org/10.32626/2227-6246.2021-53.149-172 
tural approach. So, it is a process of forming the personal position of the individual, taking into account the diversity of subjective and objective factors, which involve the implementation of strategies for managing the personal resources which are necessary for making the translation on the professional level. It was noted that the development of the translational competence of schoolchildren also involved the formation of personally significant position, which was understood by us as a system of dominant values-semantic attitudes of pupil to the socio-cultural environment, of himself/herself and his/her activities.

Therefore, the conceptual model of the development of the translational competence of schoolchildren, in our opinion, will necessarily include readiness of schoolchildren to perform the translational activity. The formation of readiness for foreign language communication and translation becomes a necessary prerequisite for the training of pupils who speak a foreign language and are able to get in touch with representatives of another culture. The readiness for foreign language communication and translation is considered by us as the integral personal new formation that involves a high level of knowledge of a foreign language, linguistics in general, as well as the pupils' possession of gaining the necessary communication skills.

We also attribute the state of readiness mainly to intellectual and volitional states, as its leading characteristics are the desire successfully to solve problems of self-development, self-improvement, creativity and confidence in the development of their abilities to translate, which can be considered as a necessary condition for volitional decision-making, management of their behavior and providing actions in order to achieve the goal of their activity. We consider the state of readiness of a pupil for self-development and self-realization as a desire of the individual to overcome internal contradictions, states of anxiety and cognitive dissonance, creative implementation of plans and programs of self-realization. The readiness of a pupil for self-development is determined by general and special knowledge, skills, mental processes, states and personality traits, and ultimately by the responsibility for the results of self-improvement and personal growth.

Conclusions. It was stated that that conceptual model would necessarily include readiness of pupils for performing the translational activity. Willingness is characterized by the different nature of the interconnections of its structural components (a cognitive component - knowledge of a foreign language, a linguistic one - linguistic competence, the component of implementation - communication skills). Considering the readiness of a pupil as a component of per(C) Ivashkevych Ernest

DOI (article): https://doi.org/10.32626/2227-6246.2021-53.149-172 
DOI: https://doi.org/10.32626/2227-6246.2021-53

2021. ВИПУСК 53

son's intercultural communication and as a set of individually significant psychological factors of a schoolchild, we (taking into account the diagnostic goals) have identified the characteristics of different levels of the development of each of the factors of readiness, which we mean as a criterion basis for studying the phenomenon of pupils' readiness for organizing the process of successful intercultural communication. The first (a cognitive) component is considered in the context of this research as varying levels of foreign language acquisition. In fact, in our opinion, a cognitive component of readiness contains the linguistic competence of the person, as well as his/her communicative skills and the peculiarities of using them in the process of translation activity.

Key words: translation activity, translational competence, willingness, a cognitive component, a linguistic component, the component of implementation, linguistic competence.

\section{Introduction}

The most important problem in learning a foreign language is its intensification. The intensification of the cognitive process should begin with the first steps in teaching children at school, since we have the aim of accelerating pupils' acquisition of gaining necessary knowledge, skills and abilities, and providing in such a way the development of a creative independent personality (Гончарук \& Онуфрієва, 2018).

Means of the intensification of teaching English may be static and dynamic video-phonograms, since they provide the interaction of auditory, visual and speech-motor analyzers of pupils, which are of great importance for teaching oral speech of foreign languages. Static video-phonograms are dynamic auditory with static video, with slide and mono-screen or TV. Within our research, the application of dynamic video-phonograms is considered as a device that provides teaching material with a combination of dynamic audio and video. Dynamic video-phonograms help to disclose the essence of the language phenomenon having been studied. They act as the effective means of modeling the fragments of the objective reality (Михальчук \& Онуфрієва, 2020).

(C) Ivashkevych Ernest

DOI (article): https://doi.org/10.32626/2227-6246.2021-53.149-172 
DOI: https://doi.org/10.32626/2227-6246.2021-53

2021. випуск 53

The dynamic video-phonogram performs informative and stimulating didactic functions in learning. The action of an informative function is ensured by the reception of new information on the linguistic, extra-linguistic and paralinguistic levels. The stimulating function is that one when the videophonogram mobilizes the pupils' mental activity: it causes a great interest at foreign language lessons, transforms arbitrary attention into involuntary one, activates and develops pupils' creative imagination.

Then we turn to the consideration of the functioning of visual and auditory perception in the process of teaching oral speech, which are combined into active processes, as well as their influence on the person's thinking. The psychological basis of any dynamic video-phonogram is the visual image, which is defined by us as the unity of sensory and rational reflection of the reality and arises as a result of practical and cognitive activity.

Pupils of 10-15 years old have a high level of visual memory, which depends on the intense development of the person's visual perception. The visual activity of children of 10-15 years old is increased by $60 \%$ compared with the visual images of the seven-year-old children; a sensitivity to shade the colors which are almost quickly increased. The development of visual perception improves visual memory of a pupil. In addition, in the visual memory of teens, spatial characteristics are already fixed.

Scientists also notice a significant development of auditory perception of children of 10-15 years old. But the processes of perception and reproduction of the visual and auditory images are not yet sufficiently formed, and because of this reason we require good management of the process of perception of audiologists (Максименко, Ткач, Литвинчук \& Онуфрієва, 2019).

The video-phonogram differs from purely sound means of teaching a qualitatively different psychic effect on pupils, which is due to the fact that with the onset of its demon(c) Ivashkevych Ernest

DOI (article): https://doi.org/10.32626/2227-6246.2021-53.149-172 
stration the appearance of stimuli is associated not only with the auditory level of reception, but also with the visual appearance of a series of bright light spots on the screen that are rapidly changing. Simultaneous excitation of the auditory analyzer and the center of vision causes a reorganization of the physiological state of certain areas of the cerebral cortex. There is a new psychic reaction that quickly prepares the body for receiving absolutely new information. The central nervous system of a pupil becomes especially active, which affects the speed and breadth of mental processes, as well as the process of perception and analysis of new feelings. Thus, the beginning of the demonstration of the video-phonogram's results in an active psycho-physiological state of the nervous system of the individual, that promotes the learning of information and to a large extent influences the person's thinking, memory and attention (Івашкевич \& Коваль, 2020).

In such a way, the aim of the article is to show the types of video material which help to develop the translational competence of teens; to determine the structural components of willingness of pupils to provide translational activity.

\section{Methods of the research}

Taking into account the impotence of the conventional methods of scientific research while dealing with the object of our article, the most substantial part of the methodological base for this research has been developed by us. As for general scientific methods, such of them as the method of induction, deduction, analysis and synthesis, comparative and descriptive methods and explanatory ones were also used quite successfully.

\section{Results and their discussion}

The data on the processing of verbal sounds and non-verbal visual information through the person's thinking are of great importance. Impulses that come from the visual images, in a great degree activate the activity of the cerebral cortex.

(C) Ivashkevych Ernest

DOI (article): https://doi.org/10.32626/2227-6246.2021-53.149-172 
DOI: https://doi.org/10.32626/2227-6246.2021-53

2021. випуск 53

That's why it follows that auditory perception can be regarded as a thoughtful operation in the process of thought activity. The development of pupils' perceptions and comprehension of audiovisual materials implies the teaching of thoughts' operations. The formation of certain skills and abilities of auditory perception promotes the assimilation of linguistic knowledge, their application in foreign language teaching. Therefore, the improvement of thought-based operations of the auditory perception of speech will be a great help of the video-phonogram in a condition for successful teaching of oral speech in other languages.

Consequently, auditory perception is a conscious intellectual process, which involves a certain degree of the development of thinking processes. The processing of verbal and visual information, understanding the meaning of the message occurs the internal perception of visual images. This means that when teens are studying a foreign language, the teacher has also to take into account the nature of internal speech.

The above data of the connection of auditory perception and the person's thinking prove the need for a detailed consideration of psychological peculiarities of mental activity of schoolchildren of 10-15 years old. According to General Psychology, for children of this age there is a positive transition from visual thinking to its abstract forms, which is due to physiological changes in the teens' brain.

Scientists have proved that pupils of seven and partially eight years old according to the peculiarities of their thinking have a visual figurative character, while in the structure of mental activity of teens of 10-15 years old there are significantly abstract components.

Also the educational activity makes a great contribution to the formation of the foundations of theoretical thinking and awareness, and related analytical abilities. Thus, valid educational and methodological complexes for secondary schools provide the development of an abstract form of thinking (c) Ivashkevych Ernest

DOI (article): https://doi.org/10.32626/2227-6246.2021-53.149-172 
through the inclusion of comparatively in-depth knowledge of them. The process of the formation of scientific concepts involves the development of such thought-based operations as analysis, synthesis, comparison, synthesis, abstraction, specification, systematization and understanding of causal relationships (Коломінова, 2000). The acquisition of knowledge, in its turn, predetermines the development of productive thinking associated with the independent use of knowledge in solving cognitive and practical tasks.

Thus, the research of the peculiarities of the development of mental operations of schoolchildren of 10-15 years old confirms their ability to comprehend the educational material, presented dynamically audio-visual characteristics. Providing educational material for emotional coloring through the videophonogram promotes even greater development of pupils' thinking.

When learning a foreign language with the help of the video-phonogram it is important to take into account the role of memory in the process of its studying. Successful functioning of memory in the process of teaching depends on many factors: from the contents of objects that are remembered, from activities with objects, from the frequency of use of the same material and to the individual characteristics of the organization of memory of teens. The physiological basis of memorization and reproduction are such processes that occur in the cerebral cortex of the person. When the object is perceived by the child through visual, auditory or other means in the corresponding nerve cells of the cerebral cortex, an excitation process that is the characteristics of the active state of cells occurs. This process changes the cells, and this change does not disappear immediately after the object ceases to act on the sensory organs. The change remains for a long time in the form of a trace remaining after the influence of the subject on the sensory organs. Strong excitation of the nerve cells of the brain leaves deep marks in the memory of pupils. Taking into account the

(c) Ivashkevych Ernest

DOI (article): https://doi.org/10.32626/2227-6246.2021-53.149-172 
DOI: https://doi.org/10.32626/2227-6246.2021-53

2021. випуск 53

strong mental impact of the video graph on pupils, we can assume that bright visual and auditory images of the video record leave deep marks in the memory of schoolchildren. The memory of schoolchildren, as well as thinking, still has a specific-figurative character and it is divided into the following types: short-term memory, operational and long-term ones.

Short-term memory plays an exclusive role in the process of perceiving and understanding the speech message. Under the influence of training, the volume of short-term auditory and visual memory of teens is gradually increasing. Studies also show a clear connection between the volume of short-term auditory and visual memory and provide the success of schoolchildren. The development of short-term memory positively affects pupils' ability to perform different tasks. For example, in the process of performing tasks, $47 \%$ of pupils of this age remember the task for the first time, and only $1.7 \%$ of pupils are not able to perform the task due to reasons for not memorizing it.

The component of short-term memory, the basis of functioning of which is the mechanism of equivalent substitutions in the process of perception of information, allows the person to keep in memory a large amount of information by increasing its operational units: words, phrases, over-the-fold unities and their blocks. With the help of these operational units there is a process of transformation of memory processes from direct fixation and reproduction into a complex purposeful-selective activity, which involves various operations of thinking.

Sharp enhancement of short-term memory of pupils of 1015 years old affects the development of long-term memory.

Well-remembered material, which is the immediate goal of the activity, is meaningful and relevant to the child's past personal experience. Successful learning of learning material depends on the nature of the activity, the degree of its complexity, the activity of the individual and also the emotional color of the activity.

(C) Ivashkevych Ernest

DOI (article): https://doi.org/10.32626/2227-6246.2021-53.149-172 
Consideration of the regarding memory processes would be incomplete without taking into account the importance which plays the important role in these processes. Conducting educational activities the attention of the child is influenced by two groups of factors that determine teens' orientation the factors that characterize the structure of external stimuli (strength, intensity, novelty), and factors relating to the personality of the child and the conditions of his/her activity: needs, interest, business atmosphere, complexity and variety of educational tasks, availability of humor; sanitary and hygiene conditions of teaching are also important.

Psychological preconditions are also necessary for the usage of video-phonogram in the process of teaching a foreign language at secondary school. The main of them are the sufficient level of mental development of schoolchildren of 10-15 years old. Characteristic features of this age category are the intensive development of operations of arbitrary perception, thinking, memory, the attention and the ability to organize pupils' activities arbitrarily, which creates conditions for the successful completion of tasks with the use of video materials. This is very important, because the pupil has to perceive the audiovisual material and keep the auditory and visual information in memory at the same time. So, the video-phonogram stimulates the processes of memory, facilitates the perception and comprehension of the educational material, causes an increased interest in teaching, which contributes to its assimilation. The visual images of the dynamic video-phonograms support and facilitate the auditory perception, help the person to understand a verbal message that is presented in specific communication situations. In our opinion, the video-phonogram will positively influence the increase of teens' attention, its constancy and switching influences, on the development of the arbitrariness attention, because it is a new strong stimulus that attracts the attention of pupils, if it is in line with their age-specific features and interests. The video game of 
DOI: https://doi.org/10.32626/2227-6246.2021-53

2021. випуск 53

the video-phonogram helps pupils separate the main information from the secondary one, produces an emotional influence, contributes to the focus of the person's attention and directs him/her in a right direction. Taking into account the data of psychological studies concerning the processes of auditory and visual perception, we consider it quite natural to expect the effectiveness of dynamic auditory educational facilities in the process of teaching at school.

Having substantiated the possibility and feasibility of using video-phonograms in teaching English at secondary school, we consider it necessary to point out the peculiarities of mastering oral English speaking with the help of video-phonograms in secondary type of educational institutions. All these conditions help to develop teens' translational competence.

Let us show the peculiarities of listening material evaluation, selection and adaptation in the process of teaching oral speech.

The main function of using video-phonograms in the educational process is to present samples of foreign language broadcast in a coherent context in the situations of a real communication at the lessons. A number of scientists prove that the systematic demonstration of video-phonograms stimulates and accelerates the formation of skills and abilities of pupils' speech, increases the intellectual level of teens, creates a positive atmosphere in the classroom.

When considering the peculiarities of the use of video-phonograms in the educational process, it is expedient to highlight the issues of the video-phonograms' types separately for the teaching of a foreign language at secondary school. There are video-phonograms of various purposes: educational films, educational video courses, documentaries, feature films and documentaries, cartoons, promotional films produced in our country or in a foreign one.

A great number of scientists (Mykhalchuk \& Ivashkevych, 2019) emphasize the need to use authentic educational and (C) Ivashkevych Ernest

DOI (article): https://doi.org/10.32626/2227-6246.2021-53.149-172 
non-teaching material at all levels of studying. In order to preserve artistic value and emotionality it is appropriate to use original educational material, although in school conditions. It is quite difficult to overcome the language barrier, which holds adequate understanding by teens the authentic material. Therefore, contemporary education selects such educational material, which is based not only on linguistics but also on cultural-oriented, communicative, personal approaches in teaching. This allows a teacher to use culturally significant, authentic foreign material.

Contemporary technical means allow us to present videophonograms not only from the TV screen, but also from a computer with the help of multimedia technologies. Noteworthy is the fact that for teaching foreign languages it is useful to develop electronic teaching and increasing learning kits, which consist of an electronic textbook (disk) and methodological support (educational printed materials). The multimedia technologies of the kit provide pupils with the skills and abilities according to four types of speech activity. This kit can be used in class and for pupils' individual activity.

There are many English video courses for the average English language, which the teachers use at the lessons, for example: "English - have a go», "Headway Video», "Handshake Video», "Grapevine Video», "Look Ahead», "Muzzy», "Only in America», "Project English», "Streamline English Video», "The Magic Music Man», «Video File», "VT», «Wizadora», «Wow!» and others. Authentic curriculum video courses have certain characteristics: the presentation of typical communication situations; the presence of thematically completed parts; saturation selected for the activation and assimilation of lexical units that are repeated; hierarchical increase in linguistic and emphasis on speech difficulties, gradual acceleration of the pace of speech; measuring the volume of video material for hours. Auxiliary techniques which are used to facilitate the pupils' activity with the video course: titration 
DOI: https://doi.org/10.32626/2227-6246.2021-53

2021. випуск 53

of linguistic material, the availability of a textbook with video footage text, using additional information and exercises, etc.

Educational video-phonograms, in contrast to use of non-teaching techniques, take into account the level of non-verbal and verbal communication and the speed of presentation of audio material. Information that may be difficult to understand is provided at an average speed (no more than 160 words per minute). The environments are also gradually depicted so that pupils can take visual information in details, since in the context of a quick presentation the audio visual material focuses on the center of the screen, and the pupil does not capture the details of this video.

Let us turn to the characteristics of other types of videophonograms. They include non-fiction and documentary films.

Non-academic films perform informational, educational and motivational-stimulating functions due to the reflection in their subjective images of a peculiar objective world of the country, the language of which the pupils study. Such processes stimulate emotions by their content, emphasize the game of actors, show colors and musical components.

The main features of authentic non-learning feature films in terms of teaching methods of foreign languages are: saturation with unexplored language units; a high paradigm of speech; unplanned repetition of lexical units; significant emotional impact. With the help of feature films it is useful to teach pupils to use appropriately thematically completed excerpts, such as situations of acquaintance, discussions, conversations, meeting at the table, etc.

Documentary films provide factual information on the subject. They are inherent elements, such as commentary, terrain images, visual support for any oral message. Sometimes most of the information is transmitted verbatim, and pupils need to concentrate their attention mainly on the auditory, ignoring the video. This phenomenon may occur if the speech level of the audio text of the WFG does not exceed the speech (C) Ivashkevych Ernest

DOI (article): https://doi.org/10.32626/2227-6246.2021-53.149-172 
DOI: https://doi.org/10.32626/2227-6246.2021-53

2021. випуск 53

level of teens. Documentary films include such types of videophonograms as country-specific video courses, news, comments, etc. These video-phonograms are difficult for understanding by schoolchildren, since the pace of speech is fast and in a short time much information is transmitted. But a visual image contributes to the understanding of the video-phonograms. The video essentially depicts the face of the speakers in the close-up situations. This helps pupils to use subconsciously visible articulation and head movement for better understanding of visual information. Experimental data confirms that the presentation of the speaker increases the level of the person's perception of verbal communication. The display of actions, people, objects also contributes to the understanding of the video-phonograms.

Advertising can also be used as one of the means of learning. It differs by transience and careful planning, each word and images are designed for a special effect. It should be noted that many advertisements have a word game that adversely affects the person's understanding. Therefore, it is expedient to use advertising only occasionally.

All the above-mentioned video-phonograms perform certain training functions, such as:

1. Video-phonograms implement the principle of serial synthesis, which provides poly-sensor input and processing of different information. The video-phonogram has a significant informative value of the image, the brightness and severity of auditory images, the dynamism of the video.

2. The video-phonograms facilitate the maintenance of passive lexical material of pupils, which tends to be decreased.

3. The video-phonogram provides the opportunity to replenish the active lexical material of teenagers with new lexical units.

4. The video-phonogram demonstrates extra-linguistic components and paralinguistic phenomena.

C Ivashkevych Ernest

DOI (article): https://doi.org/10.32626/2227-6246.2021-53.149-172 
DOI: https://doi.org/10.32626/2227-6246.2021-53

2021. випуск 53

5. The video-phonogram provides oral speech in all its forms, along with a cinematic representation of those life situations in which it is operated, taking into account time and space.

6. Authentic video-phonogram demonstrates spoken language, which has all the temporal characteristics.

7. The technical means of demonstration of the video-phonograms create favorable conditions for providing full control over the revision of the information: its reproduction at any time, part revision, stop for focusing on details, installation of various video-phonograms, etc.

Let's show some of the functions of the authentic videophonograms in more details.

By presenting authentic communication situations that are created under the circumstances of the environment, the video-phonogram demonstrates such important components of spoken language as extra-paralinguistic components. The sphere of extra-linguistic components concerns the functioning and the development of the entire system as a whole: how the life of the society and the language interact, the culture of the people and the language, how interethnic connections to language and other sociolinguistic phenomena influence each other. In turn, the paralinguistic components relate only to specific statements and participate in the formation of a single message. These components carry some information load, their absence makes the language mechanical and artificial.

The paralinguistic component is a system of symbols, signs having been used to transmit messages with a high degree of accuracy: gestures, facial expressions, poses, coughing, breath, exhalations, etc. They are divided into vocal, mimic and pantomime means. All these signals give a certain semantic and emotional color to each speech act. The presence of sounds effects such peculiarities as different voices, laughter, music, background noise which increases the effect of the word, raises (C) Ivashkevych Ernest

DOI (article): https://doi.org/10.32626/2227-6246.2021-53.149-172 
and supports the viewer's attention, especially of children (Mykhalchuk \& Bihunova, 2019).

In such a way we pay special attention to the role of gestures, which deserves more detailed analysis. The gesture is the most common non-verbal means of communication. Our observations show that the gesture accompanying verbal speech is an indicator of the loyalty of the speaker, that is, it emphasizes the ease with which we consider the necessary condition for the implementation of situational images. Mimics, gestures in a certain way supplement the meaning of words or play the role of a replica in a dialogue, replacing the verbal expression of the person. Often we have such a situation when facial expressions express the meaning of the speaker's speech before the speech response. Sometimes interpersonal visual perception is sufficient for understanding, that is the gesture does not require a speech supplement.

On the basis of the comparison of non-verbal means of communication of the native language with similar means of a foreign one, four groups of such means are defined: similar in performance and in meaning; similar in performance and different in meaning; similar in meaning, but different in providing; absent in teens' speech behavior. On the basis of this distribution we have analyzed and compared the gestures that are typical for the British and Ukrainians.

The first group includes non-verbal means that are identical or similar in performance, scope and use of their meaning. These are gestures of consent and refusal, a gesture of «lowering the shoulders" when one does not understand what is being discussed; rubbing hands with which a person passes positive expectations.

The second group consists of nonverbal means that are identical or similar in providing, but differ in their meanings and uses. For example, the big toe raised by the British is used on the road to stop the car. And in Ukraine this gesture is used to express satisfaction and appreciation.

C) Ivashkevych Ernest

DOI (article): https://doi.org/10.32626/2227-6246.2021-53.149-172 
DOI: https://doi.org/10.32626/2227-6246.2021-53

2021. випУСК 53

The third group consists of verbal means that match the content and the scope of use, but which are different in providing. For example, when counting with fingers, Ukrainians collect fingers in their fists, and the English people, on the contrary, open fingers from the fist in their palm, with the index finger meaning «1», the middle « 2 », and the large one is « 5 »

The fourth group includes non-verbal means that are not available for the communicative behavior of the Ukrainian language carriers. For example, to show that everything is alright, the English combine the big and index fingers of the right hand, the other fingers stick directly, as if staging the word «O'key». Another gesture is the V-shaped sign with fingers, which means a victory if the hand is turned from the outside to the speaker. If the hand is turned by the palm to the speaker, this gesture receives a humiliating meaning: «I'm silent».

In the case of studying how to use the video-phonograms, we recommend the teacher draw the pupils' attention to the signatures accompanying the English language that differs from the gestures of the Ukrainian-language broadcasting.

The ability to focus pupils' attention on extra-paralinguistic information and to analyze it in details is provided by contemporary technical means with the help of a stop-frame. In addition, we allow the use of audio and video at the same time, and separately only audio or video, a video with a muted audio, apply only the beginning or the end of the video-phonograms to present excerpts of video-phonograms in a mixed sequence.

Viewing only the video, with the subsequent involvement of the audience, provides pupils the opportunity to observe the situations of communication, in which the speech act takes place, to consider paralinguistic information before concentrating attention on the speech itself. This way of using the video-phonograms develops the imagination of pupils and their abilities to predict different situations. Using the audio library helps pupils to focus on the type of speech and its temporal (C) Ivashkevych Ernest

DOI (article): https://doi.org/10.32626/2227-6246.2021-53.149-172 
DOI: https://doi.org/10.32626/2227-6246.2021-53

2021. випуск 53

characteristics before viewing the video. Such a separate use of video and audio is provided appropriately that a short videophonogram is worked out for a few minutes, and it has the aim at separating and attracting the attention of pupils to certain material that is the purpose of learning. This may be a demonstration of any situation of communication, speech or social phenomenon, pictorial image, description of a person or the event.

According to extra paralinguistic components, video-phonogram is the best among other tutorials to demonstrate emotional spoken material with various temporal characteristics. It is proved that emotional oral speech differs from calm balanced one, for example:

- in a state of sadness the pace of speech goes down to the end of the phrase; even the absurdity of the duration of individual sounds is noted, for example, the accentuated vowel is shorter than after the accent;

- for the state of fear speech is characterized by short accentuated vowels, which lead to a violation of the rhythm of words;

- in a state of rage the duration of consonants increases.

It is also investigated that in a state of fear or fierce articulation both vowel and consonants become clearer.

These data suggest that the presentation of authentic video-phonogram in a real spoken speech in the background of real situations of communication contributes to better learning, since not all teachers can produce such qualitative speech samples in different emotional states as they do as native speakers: also professional speakers, actors and others.

In this article we consider the development of the translational competence of schoolchildren from the standpoint of the cultural approach. So, it is a process of forming the personal position of the individual, taking into account the diversity of subjective and objective factors, which involve the implementation of strategies for managing the personal resources which

(C) Ivashkevych Ernest

DOI (article): https://doi.org/10.32626/2227-6246.2021-53.149-172 
DOI: https://doi.org/10.32626/2227-6246.2021-53

2021. випуск 53

are necessary for making the translation on the professional level. It was noted that the development of the translational competence of schoolchildren also involved the formation of personally significant position, which was understood by us as a system of dominant values-semantic attitudes of pupil to the socio-cultural environment, of himself/herself and his/her activities.

Therefore, the conceptual model of the development of the translational competence of schoolchildren, in our opinion, will necessarily include readiness of schoolchildren to perform the translational activity. The formation of readiness for foreign language communication and translation becomes a necessary prerequisite for the training of pupils who speak foreign language and are able to get in touch with representatives of another culture. The readiness for foreign language communication and translation is considered by us as the integral personal new formation that involves a high level of knowledge of a foreign language, linguistics in general, as well as the pupils' possession of gaining the necessary communication skills. We also attribute the state of readiness mainly to intellectual and volitional states, as its leading characteristics are the desire successfully to solve problems of self-development, self-improvement, creativity and confidence in the development of their abilities to translate, which can be considered as a necessary condition for volitional decision-making, management of their behavior and providing actions in order to achieve the goal of their activity. We consider the state of readiness of a pupil for self-development and self-realization as a desire of the individual to overcome internal contradictions, states of anxiety and cognitive dissonance, creative implementation of plans and programs of self-realization. The readiness of a pupil for self-development is determined by general and special knowledge, skills, mental processes, states and personality traits, and ultimately by the responsibility for the results of selfimprovement and personal growth.

(C) Ivashkevych Ernest

DOI (article): https://doi.org/10.32626/2227-6246.2021-53.149-172 


\section{Conclusions}

It was stated that the conceptual model would necessarily include readiness of pupils for performing the translational activity. Willingness is characterized by the different nature of the interconnections of its structural components (a cognitive component - knowledge of a foreign language, a linguistic one - linguistic competence, the component of implementation - communication skills). Considering the readiness of a pupil as a component of person's intercultural communication and as a set of individually significant psychological factors of a schoolchild, we (taking into account the diagnostic goals) have identified the characteristics of different levels of the development of each of the factors of readiness, which we mean as a criterion basis for studying the phenomenon of pupils' readiness for organizing the process of successful intercultural communication. The first (a cognitive) component is considered in the context of this research as varying levels of foreign language acquisition. In fact, in our opinion, a cognitive component of readiness contains the linguistic competence of the person, as well as his/her communicative skills and the peculiarities of using them in the process of translation activity.

\section{Literature}

Гончарук Наталія, Онуфрієва Ліана. Психологічний аналіз рівнів побудови комунікативних дій. Psycholinguistics. Психолінгвістика. Психолингвистика, 2018, 24 (1), 97-117. URL : https://doi: 10.31470/2309-1797-2018-24-1-97-117.

Івашкевич Е., Коваль І. Психологічні принципи організації дедуктивного процесу на уроках англійської мови в закладах середньої освіти. Збірник наукових праць «Проблеми сучасної психологї̈, 2020, 50, 31-52. URL : https://doi.org/10.32626/2227-6246.202050.31-52.

Максименко С., Ткач Б., Литвинчук Л., Онуфрієва Л. Нейропсихолінгвістичне дослідження політичних гасел із зовнішньої реклами. Psycholinguistics. Психолінгвістика. Психолингвистика, 2019, 26 (1), 246-264. URL : https://psycholing-journal.com/index.php/ journal/article/view/715.

(C) Ivashkevych Ernest

DOI (article): https://doi.org/10.32626/2227-6246.2021-53.149-172 
DOI: https://doi.org/10.32626/2227-6246.2021-53

2021. ВиПУСК 53

Михальчук Н., Онуфрієва Л. Психологічний аналіз різних типів дискурсу. Збірник наукових пращь "Проблели сучасної психологї̈, 2020, 50, 188-210. URL : https://doi.org/10.32626/2227-6246. 2020-50.188-210.

Mykhalchuk, N., \& Bihunova, S. The verbalization of the concept of «fear» in English and Ukrainian phraseological units. Cognitive Studies Études cognitives, 2019, 19, 11. Варшава (Польща). URL : https:// doi.org/10.11649/cs.2043.

Mykhalchuk, N., \& Ivashkevych, E. Psycholinguistic Characteristics of Secondary Predication in Determining the Construction of a Peculiar Picture of the World of a Reader. Psycholinguistics. Пcuxoлінгвістика. Психолингвистика, 2019, 25 (1), 215-231. URL : https://doi.10.31470/2309-1797-2019-25-1-215-231.

\section{References}

Honcharuk, Nataliia, \& Onufriieva, Liana (2018). Psykholohichnyi analiz rivniv pobudovy komunikatyvnykh dii [Psychological analysis of the levels of construction of communicative actions]. Psycholinguistics. Psykholinhvistyka. Psikholingvistika - Psycholinguistics. Psycholinguistics. Psycholinguistics, 24 (1), 97-117. Retrieved from https:// doi.10.31470/2309-1797-2018-24-1-97-117 [in Ukrainian].

Ivashkevych, E., \& Koval, I. (2020). Psykholohichni pryntsypy orhanizatsii deduktyvnoho protsesu na urokakh anhliiskoi movy v zakladakh serednoi osvity [Psychological Principles of Organization of the Deductive Process at the English Lessons at Secondary Schools]. Zbirnyk naukovykh prats "Problemy suchasnoi psykholohii» - Collection of Research Papers "Problems of Modern Psychology», 50, 31-52. Retrieved from https://doi.org/10.32626/2227-6246.202050.31-52 [in Ukrainian].

Maksymenko, S., Tkach, B., Lytvynchuk, L., \& Onufriieva, L. (2019). Neiropsykholinhvistychne doslidzhennia politychnykh hasel iz zovnishnoi reklamy [A neuropsycholinguistic research of political slogans from outdoor advertising]. Psycholinguistics. Psykholinhvistyka. Psikholingvistika - Psycholinguistics. Psycholinguistics. Psycholinguistics, 26 (1), 246-264. Retrieved from https://psycholing-journal. com/index.php/journal/article/view/715 [in Ukrainian].

Mykhalchuk, N., \& Bihunova, S. (2019). The verbalization of the concept of "fear" in English and Ukrainian phraseological units. Cognitive Studies $\mid$ Études cognitives, 19, 11. Warsaw (Poland). Retrieved from https://doi.org/10.11649/cs.2043.

(C) Ivashkevych Ernest

DOI (article): https://doi.org/10.32626/2227-6246.2021-53.149-172 
Mykhalchuk, N., \& Ivashkevych, E. (2019). Psycholinguistic Characteristics of Secondary Predication in Determining the Construction of a Peculiar Picture of the World of a Reader. Psycholinguistics. Psykholinhvistyka. Psikholingvistika - Psycholinguistics. Psycholinguistics. Psycholinguistics, 25 (1), 215-231. Retrieved from https:// doi.10.31470/2309-1797-2019-25-1-215-231.

Mykhalchuk, N., \& Onufriieva, L. (2020). Psykholohichnyi analiz riznykh typiv dyskursu [Psychological Analysis of Different Types of Discourse]. Zbirnyk naukovykh prats "Problemy suchasnoi psykholohii» - Collection of Research Papers "Problems of Modern Psychology», 50, 188-210. Retrieved from https://doi.org/10.32626/22276246.2020-50.188-210 [in Ukrainian].

Івашкевич Ернест. Психологічні аспекти використання відео для формування перекладацької компетентності підлітків

\section{АНОТАЦІЯ}

Мета статmі - презентувати типи відеоматеріалів, що фасилітують становлення перекладацької компетентності підлітків; визначити структурні компоненти готовності учнів до перекладацької діяльності.

Методи дослідження. Щодо загальнонаукових методів, то використано такі з них, як індукція, дедукція, аналіз і синтез, методи порівняння та опису, метод обгрунтування тощо.

Результати дослідження. Розглянуто становлення перекладацької компетентності школярів із позичій культурологічного підходу - як процес формування особистісної позиції індивіда з урахуванням усього різноманіття суб'єктивних і об'єктивних чинників, що передбачає реалізацію стратегій управління особистісними ресурсами, потрібними для здійснення перекладу на найбільш фаховому рівні. Становлення перекладацької компетентності школярів також передбачає формування особистісно значущої позиції, яка розуміється нами як система домінуючих ціннісно-смислових ставлень школяра до сочіокультурного оточення, самого себе і своєї діяльності.

Отже, концептуальна модель становлення перекладацької компетентності школярів, на нашу думку, обов'язково включатиме готовність учнів до виконання перекладацької діяльності. Формування готовності до здійснення іншомовного спілкування та перекладу стає необхідною передумовою підготовки школярів, які володіють іноземною мовою,

(C) Ivashkevych Ernest

DOI (article): https://doi.org/10.32626/2227-6246.2021-53.149-172 
вміють увійти в контакт із представниками іншої культури. Готовність до здійснення іншомовного спілкування та перекладу ми розглядаємо як інтегральне особистісне новоутворення, що передбачає високий рівень знань іноземної мови, лінгвокраїнознавства, а також володіння школярем потрібними комунікативними вміннями та навичками.

Ми відносимо стан готовності переважно до інтелектуально-вольових станів, оскільки його провідними характеристиками є прагнення успішно розв'язувати задачі саморозвитку, самовдосконалення, виявляти творчість і впевненість у розвитку своїх здібностей до здійснення перекладу, що можна розглядати як необхідну умову здійснення вольового процесу прийняття перекладацьких значущих рішень, управління своєю поведінкою та діями задля досягнення мети діяльності. Стан готовності школяра до саморозвитку та самореалізації ми розглядаємо як прагнення особистості до подолання внутрішніх протиріч, станів тривожності й когнітивного дисонансу, творчої реалізації планів і програм самоздійснення. Готовність учня до саморозвитку визначається загальними і спеціальними знаннями, вміннями, навичками, психічними прочесами, станами і властивостями особистості, врешті-решт - відповідальністю за результати самовдосконалення й особистісного зростання.

Висновки. Обгрунтовано, що готовність до здійснення перекладацької діяльності характеризується різним характером взаємозв'язків ії структурних компонентів (когнітивного - знання іноземної мови, лінгвокраїнознавчого - лінгвокраїнознавча компетентність, реалізаційного - комунікативні вміння). Розглядаючи готовність школяра до інтеркультурної комунікації як сукупність окремих значущих показників, ми (з урахуванням діагностичних чілей) визначили характеристику різних рівнів розвитку кожного з показників готовності, які розглядаємо як критеріальну основу для дослідження феномену готовності учнів до здійснення успішної інтеркультурної комунікації. Перший (когнітивний) показник розглянуто в контексті цього дослідження як різний рівень опанування іноземною мовою. Фактично, когнітивний показник готовності, на нашу думку, вміщує лінгвокраїнознавчу компетентність особистості, а також комунікативні вміння школяра й особливості їх використання у перекладацькій діяльності.

Ключові слова: перекладацька діяльність, трансляційна компетентність, готовність, когнітивний компонент, лінгвістичний компонент, компонент імплементації, лінгвістична компетентність.

(C) Ivashkevych Ernest

DOI (article): https://doi.org/10.32626/2227-6246.2021-53.149-172 
DOI: https://doi.org/10.32626/2227-6246.2021-53

2021. ВИПУСК 53

Ивашкевич Эрнест. Психологические аспекты использования видео для формирования переводческой компетентности подростков

\section{АННОТАЦИЯ}

Целью статьи являются презентация видеоматериалов разного типа, которые в наибольшей степени фасилитируют становление переводческой компетентности подростков; определение структурных компонентов готовности учащихся к переводческой деятельности.

Методы исследования. Из совокупности основных научных методов были использованы такие, как индукция, дедукция, анализ и синтез, методы сравнения и описания, метод обоснования.

Результаты исследования. Рассмотрено становление переводческой компетентности школьников с позиций культурологического подхода - как процесс формирования личностной позичии индивида с учетом всего многообразия субъективных и объективных факторов, что предусматривает реализацию стратегий управления личностными ресурсами, нужными для осуществления перевода на наиболее профессиональном уровне. Становление переводческой компетентности школьников также предусматривает формирование личностно значимой позиции, которая понимается нами как система доминирующих ценностно-смысловых отношений школьника к социокультурному окружению, самому себе и своей деятельности.

Доказано, что концептуальная модель становления переводческой компетентности школьников, по нашему мнению, включает готовность учащихся к выполнению переводческой деятельности. Формирование готовности к осуществлению иноязычного общения и перевода становится необходимым условием подготовки школьников, владеющих иностранным языком, которые умеют войти в контакт с представителями другой культуры. Готовность к осуществлению иноязычного общения и переводческой деятельности мы рассматриваем как интегральное личностное новообразование, что предполагает высокий уровень знаний иностранного языка, лингвострановедения, а также владение школьником необходимыми коммуникативными умениями и навыками.

Мы относим состояние готовности преимущественно к интеллектуально-волевому состоянию, поскольку его ведущими характеристиками являются стремление успешно решать задачи саморазвития, самосовершенствования, проявлять творческие умения и формировать

(C) Ivashkevych Ernest

DOI (article): https://doi.org/10.32626/2227-6246.2021-53.149-172 
DOI: https://doi.org/10.32626/2227-6246.2021-53

2021. випуск 53

уверенность в развитии своих способностей к осуществлению перевода. Последние мы рассматриваем как необходимое условие осуществления волевого прочесса принятия переводческо значимых решений, управления своим поведением и действиями с целью достижения непосредственной цели деятельности. Состояние готовности школьника к саморазвитию и самореализации мы рассматриваем как стремление личности к преодолению внутренних противоречий, состояний тревоги и когнитивного диссонанса, творческой реализации планов и программ самореализации. Готовность подростков к саморазвитию определяется общими и специальными знаниями, умениями, навыками, психическими процессами, состояниями и свойствами личности, в конце концов-ответственностью за результаты самосовершенствования и личностного pocma.

Выводы. Обосновано, что готовность к осуществлению переводческой деятельности характеризуется разным характером взаимосвязей ее структурных компонентов (когнитивного - знание иностранного языка, лингвострановедческого - лингвострановедческая компетентность, операционального - коммуникативные умения). Рассматривая готовность школьника к кросскультурной коммуникации как совокупность отдельных значимых показателей, мы (с учетом диагностических целей обучения) определили характеристику различных уровней развития каждого из показателей готовности, которые рассматриваем в качестве критериальной основы для исследования феномена готовности учащихся к осуществлению успешной кросскультурной коммуникации. Первый (когнитивный) показатель рассмотрен в контексте данного исследования как определенный уровень овладения иностранным языком. Фактически, когнитивный показатель готовности, по нашему мнению, включает лингвострановедческую компетентность, а также коммуникативные умения школьника и особенности их использования в переводческой деятельности.

Ключевые слова: переводческая деятельность, трансляционная компетентность, готовность, когнитивный компонент, лингвистический компонент, компонент имплементации, лингвистическая компетентность.

Original manuscript received April 16, 2021

Revised manuscript accepted May 30, 2021

(C) Ivashkevych Ernest

DOI (article): https://doi.org/10.32626/2227-6246.2021-53.149-172 